\title{
Synthesis, Characterization of La(III), Nd(III), and Er(III) Complexes with Schiff Bases Derived from Benzopyran-4-one and Thier Fluorescence Study
}

\author{
Aida L. El-Ansary and Nora S. Abdel-Kader \\ Department of Chemistry, Faculty of Science, Cairo University, Giza 12613, Egypt \\ Correspondence should be addressed to Aida L. El-Ansary, aidansary1@yahoo.com \\ Received 8 November 2011; Revised 18 January 2012; Accepted 18 January 2012 \\ Academic Editor: Alfonso Castiñeiras
}

Copyright ( $) 2012$ A. L. El-Ansary and N. S. Abdel-Kader. This is an open access article distributed under the Creative Commons Attribution License, which permits unrestricted use, distribution, and reproduction in any medium, provided the original work is properly cited.

The Schiff bases, $\mathrm{L}^{1}, \mathrm{~L}^{2}$, and $\mathrm{L}^{3}$, are synthesized from the condensation of 5,7-dihydroxy-6-formyl-2-methylbenzopyran-4-one (L) with 2-aminopyridine (1), p-phenylenediamine (2), and o-phenylenediamine (3). The prepared Schiff bases react with lanthanum (III), neodymium (III), and erbium (III) nitrate to give complexes with stoichiometric ratio ( $1: 1)$ (ligand: metal). The binuclear complexes of $\operatorname{Er}(\mathrm{III})$ with $\mathrm{L}^{3}$ and the three metal ions with $\mathrm{L}^{2}$ are separated. The complexes have been characterized by elemental analysis, molar conductance, electronic absorption, and infrared, ${ }^{1} \mathrm{H}$-NMR spectral studies. The presence of hydrated and coordinated water molecules is inferred from thermogravimetric analysis. Thermal degradation studies show that the final product is the metal oxide. The luminescence properties of the $\mathrm{Nd}$ (III) and Er(III) complexes in dimethylformamide (DMF) solutions were investigated.

\section{Introduction}

The coordination chemistry of lanthanide (III) ions is rapidly increasing, owing to the relevance of these compounds in basic and applied research in different scientific areas ranging from chemistry to material science to the life science [1-8]. Lanthanide coordination compounds are the subject of intense research efforts owing to their unique structures and their potential applications in advanced materials such as Lndoped semiconductors [9], magnetic [10,11], catalytic [12], fluorescent $[13,14]$, and nonlinear optical materials $[15,16]$. It has been shown that ligands containing both nitrogen and oxygen donor atoms are good building blocks for the formation of various lanthanide coordination compounds [1724]. Schiff bases continue to occupy an important position as ligands in metal coordination chemistry [25], even almost a century since their discovery. Schiff base metal complexes have played a key role in the development of coordination chemistry, resulting in an enormous number of publications, ranging from pure synthetic work to modern physicochemical and biochemically relevant studies of metal complexes [26]. The lanthanide cations can promote Schiff base condensation and can give access to complexes of otherwise inaccessible ligands.

It is essential to design appropriate ligands to optimize the luminescence properties of lanthanide ions by facilitating the well-known light conversion process, which show to be efficient ligand-to-metal energy transfer process [27]. In view of this, we have designed a series of Schiff bases, which can enhance the luminescence properties of lanthanide ions. In the present work, the complexes of rare earth $(\mathrm{La}(\mathrm{III})$, $\mathrm{Nd}(\mathrm{III})$, and $\mathrm{Er}(\mathrm{III})$ ) nitrate with the Schiff bases derived from the condensation of aromatic amine (2-aminopyridine (1)), aromatic diamines (p-phenylenediamine (2)), and o-phenylenediamine (3)) with 5,7-dihydroxy-6-formyl-2methylbenzopyran-4-one (L) were synthesized. Their structures were characterized by elemental analysis, molar conductance, IR, UV-Vis, ${ }^{1} \mathrm{H}$ NMR, and thermal analysis. The luminescence properties of the $\mathrm{Nd}$ (III) and $\mathrm{Er}$ (III) complexes in dimethylformamide (DMF) solutions were investigated. 


\section{Experimental}

2.1. Materials and Reagents. All materials and solvents employed in this study were chemically pure grade. They included 2-aminopyridine, p-phenylenediamine, o-phenylenediamine, 5-methoxy-2-methyl-furanobenzopyran-4-one, potassium dichromate, sulphuric acid, hydrochloric acid, dimethylformamide (DMF), and dimethylsulfoxide (DMSO). The rare earth (III) nitrates were prepared by dissolving $\mathrm{La}_{2} \mathrm{O}_{3}, \mathrm{Nd}_{2} \mathrm{O}_{3}, \mathrm{Er}_{2} \mathrm{O}_{3}$ (99.95\%, Aldrich) in concentrated nitric acid and crystallizing the salts by evaporating the solution on a steam bath.

2.2. Analysis and Physical Measurements. Carbon, hydrogen, and nitrogen were analyzed by standard microanalysis methods at microanalytical center, Cairo University, Giza, Egypt. UV-Vis spectra of the metal complexes in DMF were recorded on UV/Vis-NIR 3101 PC Shimadzu spectrophotometer. IR spectra of the ligands and their metal complexes, as $\mathrm{KBr}$ discs, were recorded on a Shimadzu FTIR spectrometer. ${ }^{1} \mathrm{H}-\mathrm{NMR}$ spectra of the ligands and their $\mathrm{La}$ (III) complexes, in DMSO-d6, were recorded on Varian $300 \mathrm{MHz}$ NMR spectrometer at room temperature using TMS as an internal standard. Molar conductivity of $10^{-3} \mathrm{~mol} \mathrm{~L}^{-1}$ solutions of the complexes in DMF was measured on the conductivity meter ORION model 150 of 0.6 cell constant. Thermal analyses have been carried out using Shimadzu-50 thermal analyzer from room temperature to $800^{\circ} \mathrm{C}$ under heating rate of $10^{\circ} \mathrm{C} \mathrm{min}^{-1}$. Analysis of the metal ions was carried out by dissolving the complexes in concentrated nitric acid followed by hydrogen peroxide, neutralizing the diluted aqueous solutions with sodium hydroxide to $\mathrm{pH}$ 5.5, and the metal content was determined by recommended method [28] or was determined by the weight of the complex residue after thermal decomposition. The fluorescence property of all Schiff bases and their neodymium (III) and erbium (III) complexes in dimethylformamide (DMF) was studied. $0.25 \mathrm{~mL}$ from $10^{-4} \mathrm{~mol} \mathrm{~L}^{-1}$ stock solution is diluted to $50 \mathrm{~mL}$ by DMF to prepare $5 \times 10^{-7} \mathrm{~mol} \mathrm{~L}^{-1}$. The measurements were made on a T80t PG spectrofluorophotometer equipped with quartz cuvettes of $1 \mathrm{~cm}$ path length. The excitation and emission slit widths were $7.5 \mathrm{~nm}$ and scan speed $500 \mathrm{~nm} / \mathrm{min}$.

\subsection{Synthesis}

2.3.1. Synthesis of the Schiff-Bases. 6-Formyl-7-hydroxy-5methoxy-2-methylbenzopyran-4-one was synthesized as previously discussed [29] by oxidation of two grams of 5-methoxy-2-methyl-furanobenzopyran-4-one with chromic acid [ $60 \mathrm{~mL}$ of $10 \% \mathrm{H}_{2} \mathrm{SO}_{4}$ and $40 \mathrm{~mL}$ of $10 \% \mathrm{~K}_{2} \mathrm{Cr}_{2} \mathrm{O}_{7}$ ] at 70 $80^{\circ} \mathrm{C}$ with constant stirring, and then hydrolyzed by refluxing one gram with $25 \mathrm{~mL} \mathrm{1:1} \mathrm{hydrochloric} \mathrm{acid} \mathrm{for} \mathrm{about}$ one hour. The yellow orange product of 5,7-dihydroxy-6formyl-2-methylbenzopyran-4-one (L) was filtered, dried, and recrystallized from toluene till constant melting point $\left(195^{\circ} \mathrm{C}\right)$ [lit. m.p. 195] [30]. The Schiff bases were prepared by the addition of p-phenylenediamine, o-phenylenediamine (5 mMole), or 2-aminopyridine (10 mMole) in $20 \mathrm{~mL}$ ethanol dropwise with continuous stirring to a solution of
(L) in ethanol ( $20 \mathrm{~mL}, 10 \mathrm{mMole})$, Figure 1 . The mixture was stirred at room temperature for at least $30 \mathrm{~min}$, and the solids obtained were filtered off, washed with ethanol, and recrystallized from dimethylformamide.

2.3.2. Synthesis of the Metal Complexes. All the complexes were prepared by mixing requisite amount of the ligand and the $\mathrm{Ln}\left(\mathrm{NO}_{3}\right)_{3}$ ( $\mathrm{Ln}: \mathrm{La}(\mathrm{III}), \mathrm{Nd}(\mathrm{III})$, or $\left.\mathrm{Er}(\mathrm{III})\right)$ sufficient to form $1: 1,1: 2$, and $2: 1(\mathrm{M}: \mathrm{L})$ chelates as follows: an ethanolic solution $(10 \mathrm{~mL})$ of $\mathrm{Ln}\left(\mathrm{NO}_{3}\right)_{3}$ was added dropwise to ethanolic solution of Schiff base $\left(\mathrm{L}^{1}, \mathrm{~L}^{2}\right.$ or $\left.\mathrm{L}^{3}\right)(30 \mathrm{~mL})$. The mixtures were heated under reflux for 4-6 hours, and then the solutions were reduced to $15 \mathrm{~mL}$. The resulting solid complexes were filtered out, washed thoroughly with successive portions of hot ethanol, followed by petroleum ether until the filtrate becomes colorless. The obtained complexes were kept in a vacuum desiccator over anhydrous calcium chloride. The complexes are air stable in the solid state and soluble in DMF or DMSO.

\section{Results and Discussion}

The present study aims to investigate the structure of lanthanide ion complexes with the prepared ligands. These ligands have many centers of chelation; thus, making the elucidation and assignment of the chelation centers a challenge, the solving of this problem is tried through the investigation of the separated complexes using elemental analyses, molar conductance, electronic absorption and infrared, ${ }^{1} \mathrm{H}-\mathrm{NMR}$ and thermogravimetric analysis. The complexes are stable in air, nonhygroscopic, and have high melting point $>350^{\circ} \mathrm{C}$, and they are easy soluble in DMF and DMSO and slightly soluble in nonpolar solvents. The $\mathrm{C}, \mathrm{H}, \mathrm{N}$, Ln contents of both theoretically calculated, and measured values are in accordance with the tentative formula of the complexes. The analytical and physical data of the metal complexes of $\mathrm{L}^{1}$, $\mathrm{L}^{2}$, and $\mathrm{L}^{3}$ are shown in Table 1 . The molar conductivities of $10^{-3} \mathrm{~mol} \mathrm{~L}^{-1}$ solutions in dimethylformamide (DMF) of the given complexes were measured, Table 1. The molar conductance of the solutions of $\mathrm{L}^{1}$ complexes, $\mathrm{Nd}-\mathrm{L}^{3}$ and $(2: 1)(\mathrm{M}: \mathrm{L})$ complexes of $\mathrm{L}^{2}$ are in the range of $108-124 \mathrm{ohm}^{-1} \mathrm{~cm}^{2} \mathrm{~mol}^{-1}$, showing that complexes are $1: 1$ electrolytes [31]. On the other hand, the value of $157.80 \mathrm{ohm}^{-1} \mathrm{~cm}^{2} \mathrm{~mol}^{-1}$ for $\mathrm{Er}_{2}-\mathrm{L}^{3}$ is higher than the expected value for a $1: 1$ electrolyte which suggests that this complex is $1: 2$ electrolyte [32]. The molar conductance of the solution of La- $\mathrm{L}^{3}$ complex and $1: 1(\mathrm{M}: \mathrm{L})$ complexes of Schiff base $\mathrm{L}^{2}$ are in the range of $22.5-38.3 \mathrm{ohm}^{-1} \mathrm{~cm}^{2} \mathrm{~mol}^{-1}$. These low values may be attributed to the coordination of anion in these complexes rather than the ionic association to the lanthanide (III) cations during complex formation. This directly supports the nonelectrolytic character of these complexes [31]. Unfortunately, attempts to prepare single crystals for X-ray diffraction studies were unsuccessful.

\subsection{Characterization of the Complexes}

3.1.1. IR Spectra of the Ligands and Their Complexes. The infrared spectra of the prepared complexes are compared with 


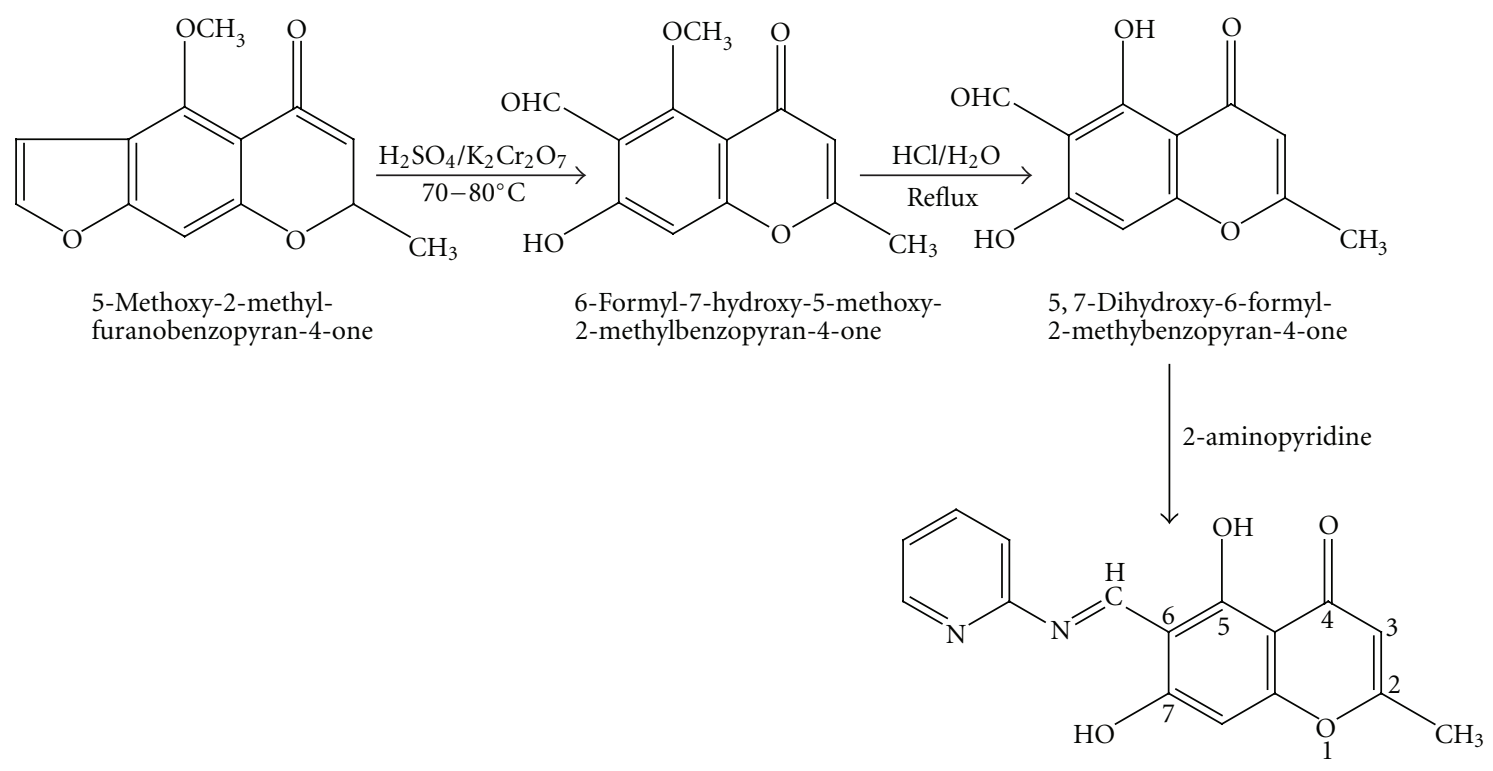<smiles>Cc1cc(=O)c2c(O)c(C=O)c(O)cc2o1</smiles>

Schiff base $\mathrm{L}^{1}$

5, 7-Dihydroxy-6-formyl-

2-methybenzopyran-4-one

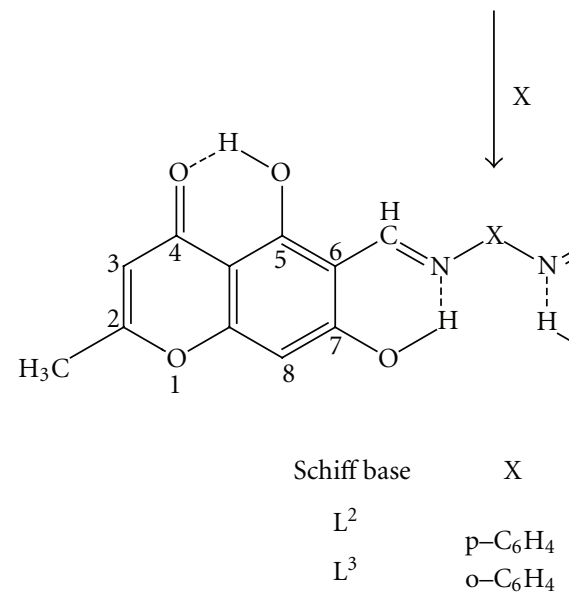

FIgure 1: Preparation of the Schiff bases.

those of the free ligands in order to determine the site of coordination that may be involved in chelation (Table 2). There are some guide peaks in the spectra of the ligands which are of good help for achieving this goal. These peaks are expected to be involved in chelation. The presence of the broad band at $3430-3364 \mathrm{~cm}^{-1}$ of the stretching vibrations of phenolic $\mathrm{OH}$ groups in the IR spectra of the ligands indicate that the $\mathrm{OH}$ groups of these Schiff bases are involved in intramolecular hydrogen bonds [33]. On the other hand, the broadbands around $3425-3417 \mathrm{~cm}^{-1}$ in the IR spectra of the complexes are due to $\nu(\mathrm{OH})$ of water molecules in the prepared complexes; this finding is also confirmed by elemental and thermal analyses.

The presence of bands with different intensities in the IR spectra of the Schiff bases at $1167-1228 \mathrm{~cm}^{-1}$ and 1109 $1119 \mathrm{~cm}^{-1}$ are due to $\mathrm{C}-\mathrm{OH}$ stretching and deformation of $\mathrm{OH}$, respectively [33]. Coordination, through the phenolic oxygen after deprotonation, causes the shift of this band to higher frequency in all the complexes compared to that of the free ligands, suggesting that hydroxyl groups of the Schiff 


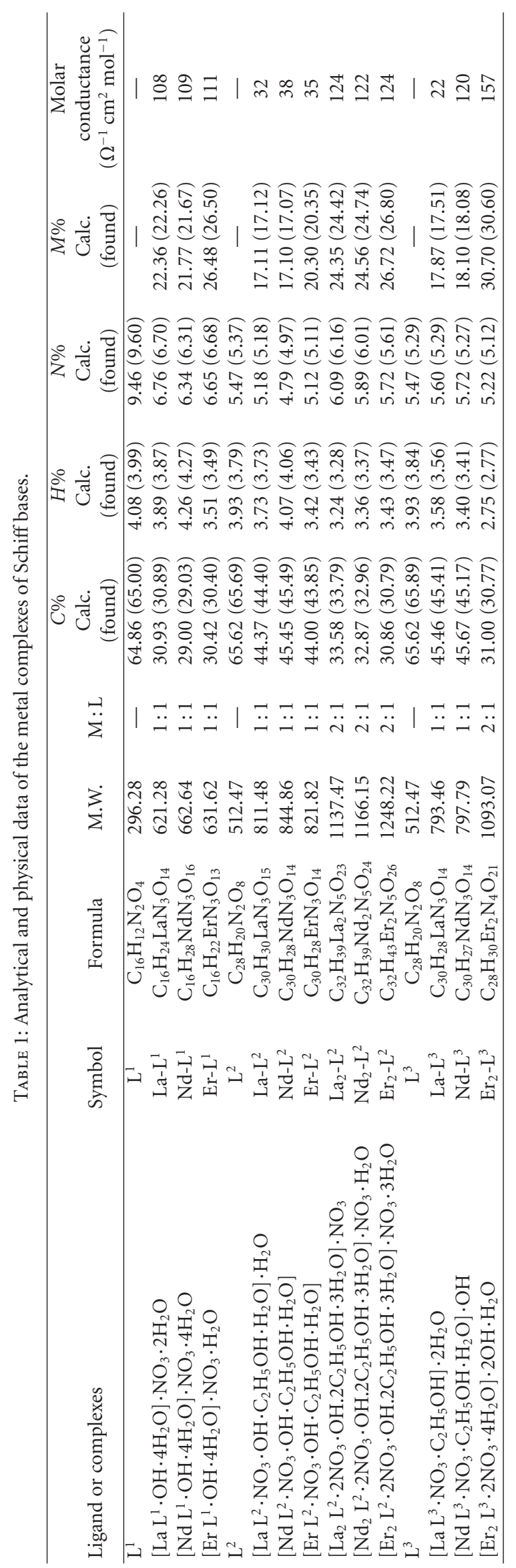




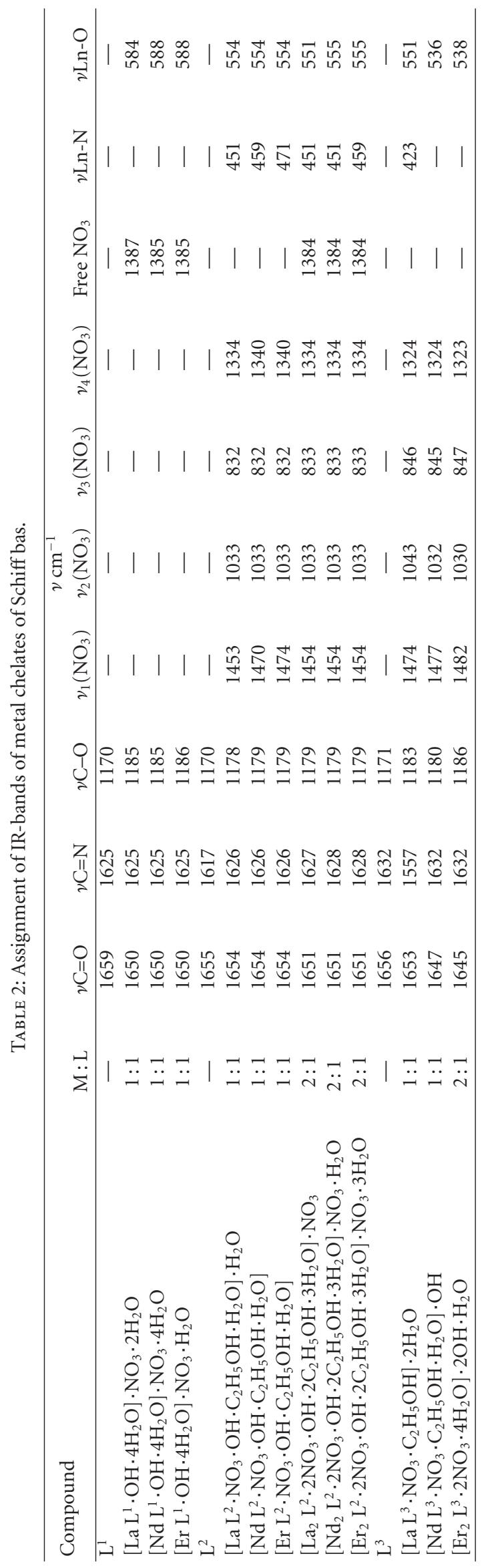


bases coordinate with $\mathrm{Ln}$ in $\mathrm{C}-\mathrm{O}-\mathrm{Ln}$ bond $[34,35]$. The IR spectra of the Schiff bases $\mathrm{L}^{1}, \mathrm{~L}^{2}$, and $\mathrm{L}^{3}$ show strong $\mathrm{C}=\mathrm{O}$ stretching band at 1658,1655 , and $1656 \mathrm{~cm}^{-1}$, respectively [36], and the IR spectra of the three Schiff bases show the stretching vibration of azomethine group at 1625,1617 , and $1632 \mathrm{~cm}^{-1}[36]$, respectively. The shift of the characteristic band of the carbonyl group to lower wave number (Table 2) in the infrared spectra of all $\mathrm{L}^{1}$ complexes, $\mathrm{Nd}(\mathrm{III})$, and $\mathrm{Er}(\mathrm{III})$ complexes of $\mathrm{L}^{3}$ indicates that the involvement of the carbonyl group in position four in the interaction with the metal ion and the $\mathrm{OH}$ group in position five of benzopyran-4-one $\left(\mathrm{C}_{5}-\mathrm{OH}\right)$ is deprotonated. Mean while, the IR spectra of $\mathrm{L}^{2}$ and $\mathrm{La}-\mathrm{L}^{3}$ complexes show a shift in the $\nu \mathrm{C}=\mathrm{N}$ (azomethine group) band towards higher or lower wave number, Table 2 , indicating that the chelation occurs in these complexes through the azomethine group $[37,38]$ and deprotonated hydroxyl group in position seven of the benzopyran-4-one moiety $\left(\mathrm{C}_{7}-\mathrm{OH}\right)$. This is confirmed by appearance of new weak bands in the range of $471-423 \mathrm{~cm}^{-1}$ in the IR spectra of $\mathrm{L}^{2}$, and $\mathrm{La}-\mathrm{L}^{3}$ complexes are tentatively assigned to $\nu \mathrm{Ln}-\mathrm{N}[27,39-41]$.

The appearance of the new bands in the spectra of the isolated solid complexes in the range $588-563 \mathrm{~cm}^{-1}$ with different intensities is characteristic for the stretching vibration of Ln-O [42-44]. These bands are not present in the IR spectra of the ligands.

A nitrate ligand can coordinate to the metal ion in three types, as monodentate, bidentate ligand, or uncoordinated ion [45-51]. The IR spectra of of $1: 1(\mathrm{M}: \mathrm{L})$ complexes of Schiff base $\mathrm{L}^{2}$ give a $\left|v_{4}-\nu_{1}\right|$ separation in the range 119$134 \mathrm{~cm}^{-1}$ suggesting monodentate bonding for the nitrate group [48]. For $\mathrm{L}^{3}$ complexes, the separation $\left|v_{4}-v_{1}\right|$ is approximately $150-165 \mathrm{~cm}^{-1}$ so in these complexes the nitrate group coordinated as bidentate ligand [49-51]. The presence of nitrate as counter ion was indicated from the IR spectra of $\mathrm{L}^{1}$ and 2:1 $(\mathrm{M}: \mathrm{L})$ complexes of $\mathrm{L}^{2}$. These complexes show a band at $1384-1387 \mathrm{~cm}^{-1}[45-47]$.

3.1.2. ${ }^{1}$ H-NMR Spectra of the Ligands and Their Complexes. The stoichiometry of the complexes is determined by recording the chemical shifts of the hydroxyl protons and the $\mathrm{HC}=\mathrm{N}$ protons of the produced complexes. The ${ }^{1} \mathrm{H}$ NMR spectral data are listed in Table 3. The two types of hydroxyl groups are unequivalent in the present ligands and their complexes. The resonance at $\delta=14.45(1 \mathrm{H}), 16.10(2 \mathrm{H})$ and $15.20(1 \mathrm{H}), 14.84(1 \mathrm{H}) \mathrm{ppm}$ in the spectra of free ligands are due to $\mathrm{C}_{5}-\mathrm{OH}$ of $\mathrm{L}^{1}, \mathrm{~L}^{2}$, and $\mathrm{L}^{3}$, respectively. The downfield shift of these protons may be due to the decrease of electron density by hydrogen bond formation with carbonyl group in position four of benzopyran-4-one [52]. This signal cannot be seen in the spectra of the $\mathrm{L}^{1}-\mathrm{Ln}$ and $\mathrm{L}^{3}-\mathrm{Er}_{2}$ complexes suggesting deprotonation of the $\mathrm{C}_{5}-\mathrm{OH}$ when the ligand coordinates to the metal ion. The signals of the azomethine $(\mathrm{HC}=\mathrm{N})$ groups show no significant shift in the ${ }^{1} \mathrm{H}$-NMR spectra of these complexes.

The upfield shift $(13.00-13.10 \mathrm{ppm}, 1 \mathrm{H})$ of $\mathrm{C}_{7}-\mathrm{OH}$ signal in the spectra of $L^{2}(1: 1)(\mathrm{M}: \mathrm{L})$ complexes is due to deprotonation of one $\mathrm{C}_{7}$ hydroxyl groups. On the other
TABLE 3: The most important data of proton NMR spectra of the Schiff and their complexes.

\begin{tabular}{lccc}
\hline Symbol & $\mathrm{C}_{5}-\mathrm{OH}$ & $\mathrm{C}_{7}-\mathrm{OH}$ & $\mathrm{CH}=\mathrm{N}$ \\
\hline $\mathrm{L}^{1}$ & $14.45 \mathrm{~s}, 1 \mathrm{H}$ & $13.63 \mathrm{~s}, 1 \mathrm{H}$ & $10.21 \mathrm{~s}, 1 \mathrm{H}$ \\
$\mathrm{La}^{-} \mathrm{L}^{1}$ & - & $13.63 \mathrm{~s}, 1 \mathrm{H}$ & $10.21 \mathrm{~s}, 1 \mathrm{H}$ \\
$\mathrm{Nd}-\mathrm{L}^{1}$ & - & $13.63 \mathrm{~s}, 1 \mathrm{H}$ & $10.22 \mathrm{~s}, 1 \mathrm{H}$ \\
Er-L $^{1}$ & - & $13.63 \mathrm{~s}, 1 \mathrm{H}$ & $10.23 \mathrm{~s}, 1 \mathrm{H}$ \\
$\mathrm{L}^{2}$ & $16.10 \mathrm{~s}, 2 \mathrm{H}$ & $14.30 \mathrm{~s}, 2 \mathrm{H}$ & $10.24 \mathrm{~s}, 2 \mathrm{H}$ \\
$\mathrm{La}^{2} \mathrm{~L}^{2}$ & $16.10 \mathrm{~s}, 2 \mathrm{H}$ & $13.00 \mathrm{~s}, 1 \mathrm{H}$ & 10.12, \\
& & & $10.24 \mathrm{~d}, 1 \mathrm{H}$ \\
$\mathrm{Nd}-\mathrm{L}^{2}$ & $16.10 \mathrm{~s}, 2 \mathrm{H}$ & $13.05 \mathrm{~s}, 1 \mathrm{H}$ & 10.12, \\
$\mathrm{Er}^{-\mathrm{L}^{2}}$ & $16.10 \mathrm{~s}, 2 \mathrm{H}$ & $13.10 \mathrm{~s}, 1 \mathrm{H}$ & $10.24 \mathrm{~d}, 1 \mathrm{H}$ \\
$\mathrm{La}_{2}-\mathrm{L}^{2}$ & $16.10 \mathrm{~s}, 2 \mathrm{H}$ & - & $10.24 \mathrm{~d}, 1 \mathrm{H}$ \\
$\mathrm{Nd}_{2}-\mathrm{L}^{2}$ & $16.10 \mathrm{~s}, 2 \mathrm{H}$ & - & $10.00 \mathrm{~s}, 2 \mathrm{H}$ \\
$\mathrm{Er}_{2}-\mathrm{L}^{2}$ & $16.10 \mathrm{~s}, 2 \mathrm{H}$ & - & $10.00 \mathrm{~s}, 2 \mathrm{H}$ \\
$\mathrm{L}^{3}$ & $15.20,14.84 \mathrm{~s}, 1 \mathrm{H}$ & $14.26,13.04 \mathrm{~s}, 1 \mathrm{H}$ & $10.23 \mathrm{~s}, 2 \mathrm{H}$ \\
$\mathrm{La}^{2} \mathrm{~L}^{3}$ & $15.20,14.84 \mathrm{~s}, 1 \mathrm{H}$ & - & $10.00 \mathrm{~s}, 2 \mathrm{H}$ \\
$\mathrm{Nd}^{2} \mathrm{~L}^{3}$ & $14.00 \mathrm{~s}, 1 \mathrm{H}$ & $14.26,13.04 \mathrm{~s}, 1 \mathrm{H}$ & $10.21 \mathrm{~s}, 2 \mathrm{H}$ \\
$\mathrm{Er}_{2}-\mathrm{L}^{3}$ & - & $14.26,13.04 \mathrm{~s}, 1 \mathrm{H}$ & $10.22 \mathrm{~s}, 2 \mathrm{H}$ \\
\hline
\end{tabular}

hand, the azomethine resonance is splitted to doublet at $10.12(1 \mathrm{H})$ and $10.24(1 \mathrm{H}) \mathrm{ppm}$ as a result of the involvement of one of $\mathrm{HC}=\mathrm{N}$ in the chelation. For $\mathrm{L}^{2}$ binuclear complexes $(2: 1)(\mathrm{M}: \mathrm{L})$, the signals due to two $\mathrm{C}_{7}-\mathrm{OH}$ are not observed and the upfield shift of $\mathrm{HC}=\mathrm{N}(\sim 0.2)$ confirming the complexation of the metal ion through the deprotonated $\mathrm{C}_{7}$ hydroxyl groups and the azomethine nitrogen.

The magnetic environment of the hydroxyl protons is not equivalent for $\mathrm{L}^{3}$ ligand, and this behavior shows a different complex formation with the three metal ions. For the mono nuclear $1: 1 \mathrm{La}-\mathrm{L}^{3}$ complex, the two signals at 14.26 and $13.04 \mathrm{ppm}$ disappeared completely confirming the deprotonation of the two $\mathrm{C}_{7}-\mathrm{OH}$ groups in position seven when the ligand coordinates to the metal ion. The signal of the azomethine protons is shifted to $10.00 \mathrm{ppm}$, and this shift can be attributed to the effect of the metal ion on the $\mathrm{HC}=\mathrm{N}$ electron clouds upon its coordination with the nitrogen lone pair. The signals due to $\mathrm{C}_{5}-\mathrm{OH}$ protons disappeared completely in the ${ }^{1} \mathrm{H}-\mathrm{NMR}$ spectra of $\mathrm{Er}_{2}-\mathrm{L}^{3}$ complex confirming their involvement in the formation of this binuclear complex. On other hand, only one of these signals disappeared in the ${ }^{1} \mathrm{H}-\mathrm{NMR}$ spectra of mononuclear $\mathrm{Nd}-\mathrm{L}^{3}$ complex, and this is due to the deprotonation and participation in the chelation. There are significant changes in the azomethine protons, (Table 3).

3.1.3. Electronic Spectra. The electronic absorption spectra of free Schiff bases $\mathrm{L}^{1}, \mathrm{~L}^{2}$, and $\mathrm{L}^{3}$ exhibit bands at 349, 392, and $400 \mathrm{~nm}$, respectively, due to an intramolecular charge transfer (CT transition) involving the whole molecule [53]. The 
spectra of $\mathrm{L}^{2}$ and $\mathrm{L}^{3}$ show also shoulders at 325 and $346 \mathrm{~nm}$, respectively, assigned to the $\pi-\pi^{*}$ transition within the azomethine $(\mathrm{CH}=\mathrm{N})$ group [54]. The complexes of $\mathrm{L}^{1}, \mathrm{~L}^{3}$, and $(1: 1)$ complexes of $\mathrm{L}^{2}$ show band in the range of 320 $380 \mathrm{~nm}$. On the other hand, the electronic spectra of $(2: 1)$ $(\mathrm{M}: \mathrm{L}) \mathrm{La}_{2}-\mathrm{L}^{2}$ and $\mathrm{Er}_{2}-\mathrm{L}^{2}$ complexes show a band at $360 \mathrm{~nm}$ and shoulder at $420 \mathrm{~nm}$ but that of $\mathrm{Nd}_{2}-\mathrm{L}^{2}$ complex shows band at $420 \mathrm{~nm}$ and shoulder at $362 \mathrm{~nm}$. The disappearance and the shifting which occurs in the bands of the ligands can be taken as evidence for the complex formation. The absorption bands due to the $f-f$ transitions of neodymium and erbium ions could not be identified. This may be probably attributed to the fact that the $f-f$ transitions are very weak [55].

3.1.4. Thermogravimetric Analysis. In the present study, the heating rate was suitably controlled at $10^{\circ} \mathrm{C} \mathrm{min}^{-1}$, and the weight loss was measured from the ambient temperature up to $1000^{\circ} \mathrm{C}$. The residues are rare earth oxides. The weight loss for each chelate was calculated within the temperature range at which the hydrated water molecules were expelled. The experimentally found and calculated weight losses are listed in Table 4. The obtained weight loss calculations were based on thermogravimetric analysis and the calculated weight losses were calculated using the tentative formulae present in Table 1. The initial weight loss occurring in the temperature range $30-140^{\circ} \mathrm{C}$ is interpreted as loss of two $(5.78 \%)$ and four $(10.79 \%)$ crystal water molecules for $\mathrm{La}-\mathrm{L}^{1}$ and $\mathrm{Nd}-\mathrm{L}^{1}$ complexes (theoretical loss is $5.80 \%$ and $10.87 \%$ ), respectively, whereas, that at $140-250^{\circ} \mathrm{C}$ is due to the loss of four coordinated water molecules (experimental loss is $11.56 \%$ and $10.82 \%$, and theoretical loss is $11.60 \%$ and $10.87 \%$ for $\mathrm{La}^{-} \mathrm{L}^{1}$ and $\mathrm{Nd}-\mathrm{L}^{1}$, resp.). The TG curves show decomposition of the other anions and molecules [bound to the metal ion to satisfy its charge and/or its coordination number] followed by decomposition of the organic part of the chelates till a constant weight, in which the metal oxide residue is formed as final product, is obtained. In The TGA curve of $\mathrm{Er}_{2}-\mathrm{L}^{2}$ complex (Figure 2), the first weight loss of $4.52 \%$ corresponding to the elimination of the three crystal water molecules (calculated $4.33 \%$ ) occurred in the stage beginning at $50^{\circ} \mathrm{C}$ and ending at $110^{\circ} \mathrm{C}$. The second weight loss that occurs in the temperature range of $110-175^{\circ} \mathrm{C}$ is due to loss of two ethanol molecules which are coordinated to the metal ion to fulfill its coordination center [56]. After that, the complex shows the weight loss of $4.20 \%$ (calculated $4.33 \%$ ) around $175-250^{\circ} \mathrm{C}$ corresponding to three coordinated water molecules. Degradation of ligand was observed in the range of $250-550^{\circ} \mathrm{C}$. At $550^{\circ} \mathrm{C}$, the complex completely converts into $\mathrm{Er}_{2} \mathrm{O}_{3}$, and the weight becomes stable. The experimental weight value of $\mathrm{Er}_{2} \mathrm{O}_{3}$ (30.76\%) is in good agreement with the calculated one (30.64\%). The TGA curve of $\mathrm{Er}_{2}-\mathrm{L}^{3}$ shows the initial weight loss of $1.66 \%$ in the temperature range $36-61{ }^{\circ} \mathrm{C}$ interpreted as a loss of moisture and hygroscopic water molecule (calculated 1.65\%) during the drying of the complexes, whereas, the observed loss $(6.38 \%)$ at $61-$ $267^{\circ} \mathrm{C}$ is due to the loss of four coordinated water molecules (calculated 6.59\%). On further heating, the TGA curve shows decomposition of the organic part of the complexes till a

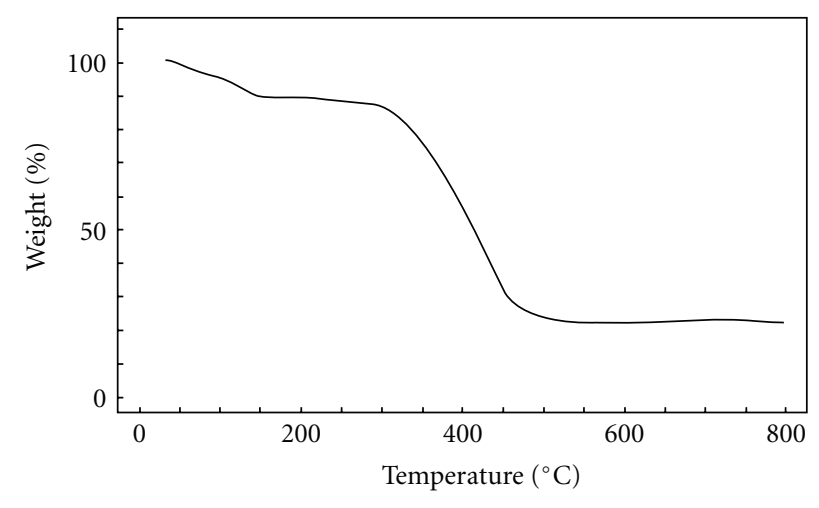

FIgURE 2: Thermogravimetric curve of $\mathrm{Er}_{2}-\mathrm{L}^{2}$ complex.

constant weight where the $\mathrm{Er}_{2} \mathrm{O}_{3}$ residue is formed as a final product. The residue weight $34.38 \%$ corresponds to $\mathrm{Er}_{2} \mathrm{O}_{3}$ (calculated 34.99\%).

3.2. Emission Spectra of Schiff Bases and Their Complexes. At room temperature, complexes of the three Schiff bases $\left(\mathrm{L}^{1}\right.$, $\mathrm{L}^{2}$, and $\mathrm{L}^{3}$ ) with $\mathrm{Nd}(\mathrm{III})$ and $\operatorname{Er}(\mathrm{III})$ metal ions exhibited emission spectra in the UV-Vis region. These photophysical properties are summarized in Table 5. It is important to mention that the lanthanum complexes of all Schiff bases are nonfluorescent. The steady-state UV-Vis emission spectra of the free Schiff bases and their complexes in DMF solutions at a concentration of $5 \times 10^{-7} \mathrm{~mol} \mathrm{~L}^{-1}$ were carried out. The photoluminescence excitation (PLE) spectrum reflects where the maximum contribution of the photoluminescence (PL) comes from. Under steady-state conditions, excited electrons relax from the highest excited states to the lowest excited states before they recombine radiatively or nonradiatively. It can be seen from Table 5 that the $\operatorname{Er}(\mathrm{III})$ and Nd(III) complexes of Schiff bases show strong emission when excited with $335 \mathrm{~nm}\left(\mathrm{~L}^{1}\right.$ and $\left.\mathrm{L}^{3}\right)$ and $330 \mathrm{~nm}\left(\mathrm{~L}^{2}\right)$. Excited wavelength varied for different complexes due to the different maximum of absorption. An excitation wavelength of $335 \mathrm{~nm}$ was utilized as it corresponds to selective irradiation of the Schiff base $\mathrm{L}^{1}$ and its complexes. The ligand emission dominating at $363 \mathrm{~nm}$ is assigned to intraligand transitions.

The emissions of the two complexes are shifted slightly to longer wavelength. Nd- $\mathrm{L}^{1}$ and Er- $\mathrm{L}^{1}$ complexes show broad emission bands at 375 and $373 \mathrm{~nm}$, respectively, indicating charge-transfer [57] nature of the transitions. The emission intensities of Nd- $\mathrm{L}^{1}$ and $\mathrm{Er}-\mathrm{L}^{1}$ complexes are stronger than that of the ligand. Significant difference from those of the ligand establishes the complexation process. At room temperature, complexes of $\mathrm{L}^{2}$ with $\mathrm{Nd}(\mathrm{III})$ and $\mathrm{Er}$ (III) metal ions exhibited similar emission spectra in the UV-Vis region. The ligand exhibits emission at $363 \mathrm{~nm}$ with intensity of 95 which is assigned to intraligand transitions when excited with $330 \mathrm{~nm}$. The emission spectra of Nd- $\mathrm{L}^{2}$ and $\mathrm{Er}-\mathrm{L}^{2}$ complexes are slightly shifted to longer wavelength and appear at $412 \mathrm{~nm}$ with intensities of 719 and 666, respectively, as 


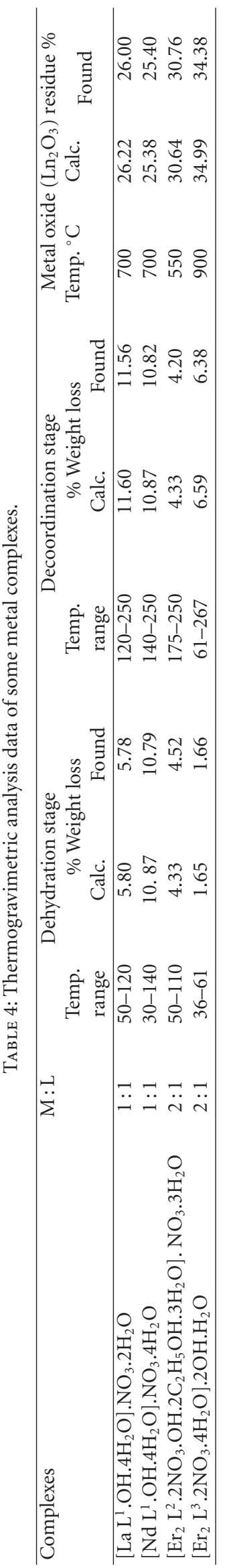


TABLE 5: Fluorescence data of ligands and their neodymium and erbium complexes in DMF.

\begin{tabular}{lccc}
\hline Symbol & $\lambda_{\text {exc. }}(\mathrm{nm})$ & $\lambda_{\text {em }}(\mathrm{nm})$ & F. I* \\
\hline $\mathrm{L}^{1}$ & 335 & 363 & 75 \\
$\mathrm{Nd}^{*} \mathrm{~L}^{1}$ & 335 & 375 & 498 \\
Er-L $^{1}$ & 335 & 373 & 203 \\
$\mathrm{~L}^{2}$ & 330 & 363 & 95 \\
$\mathrm{Nd}-\mathrm{L}^{2}$ & 340 & 412 & 719 \\
Er-L $^{2}$ & 340 & 412 & 666 \\
$\mathrm{~L}^{3}$ & 330 & 363 & 88 \\
$\mathrm{Nd}^{2} \mathrm{~L}^{3}$ & 325 & 421,448 & 104,105 \\
Er $_{2}-\mathrm{L}^{3}$ & 335 & 372,392 & 111,122 \\
\hline
\end{tabular}

${ }^{*} \mathrm{~F}$. I. is fluorescence intensity.

compared to the corresponding ligand. The difference in position of emission maximum and fluorescence from those of the ligand establishes the complexation process. It can be also seen that the emission intensities of Nd- $\mathrm{L}^{2}$ and $\mathrm{Er}-\mathrm{L}^{2}$ complexes are stronger than that of the ligand when excited with $340 \mathrm{~nm}$. The two complexes show broad emission bands indicating charge-transfer [57] nature of the transitions. The luminescence of $\mathrm{Nd}$ (III) and $\mathrm{Er}$ (III) complexes of Schiff base $\mathrm{L}^{3}$ (Figure 4) is related to the efficiency of the intramolecular energy transfer [57] between the triplet levels of the ligand and the emitting level of the ions, which depends on the energy gap between the two levels (Figure 3). In organic solvents, the energy gap between the ligand triplet level and the emitting level of the neodymium ion may be in favor of the energy transfer process than erbium. This makes the $\mathrm{Nd}$ (III) complexes show the blue emission, and the maximum emission peak of Nd- $\mathrm{L}^{3}$ complex was shifted to longer wavelength. It can be also seen that the emission intensities of $\operatorname{Er}(\mathrm{III})$ and $\mathrm{Nd}(\mathrm{III})$ complexes are stronger than that of the ligands.

\section{Structural Interpretation}

From the previous studies, the structures of the isolated complexes can be summarized as follow.

Schiff base $\mathrm{L}^{1}$ forms mononuclear complexes, and the ligand behaves as mono-negative (OO) bidentate ligand and the chelation occurs via the oxygen of carbonyl group in position four and the deprotonated phenolic oxygen atom in position five of benzopyrone, Scheme 1, the formula of complexes is suggested to be $\left[\mathrm{Ln} \mathrm{L}^{1} \cdot \mathrm{OH} \cdot 4 \mathrm{H}_{2} \mathrm{O}\right] \cdot \mathrm{NO}_{3} \cdot \mathrm{nH}_{2} \mathrm{O}$, where $\mathrm{Ln}=$ $\mathrm{La}(\mathrm{III}), \mathrm{Nd}(\mathrm{III})$, or $\operatorname{Er}(\mathrm{III})$ and $n=2,4$, or 1 .

Moreover, the Schiff base $\mathrm{L}^{2}$ forms both mononuclear and binuclear complexes. The chelation occurs through the nitrogen atom of azomethine group and the deprotoznated phenolic oxygen in position seven of the benzopyrone moiety, Schemes 2 and 3. The formula of the mononuclear complexes is suggested to be $\left[\mathrm{LnL}^{2} \cdot \mathrm{NO}_{3} \cdot \mathrm{OH}\right.$. $\left.\mathrm{C}_{2} \mathrm{H}_{5} \mathrm{OH} \cdot \mathrm{H}_{2} \mathrm{O}\right] \cdot \mathrm{nH}_{2} \mathrm{O}, \mathrm{Ln}=\mathrm{La}(\mathrm{III}), \mathrm{Nd}(\mathrm{III})$, or $\operatorname{Er}(\mathrm{III})$ and $n=1,0$ or 0 and that for binuclear complexes

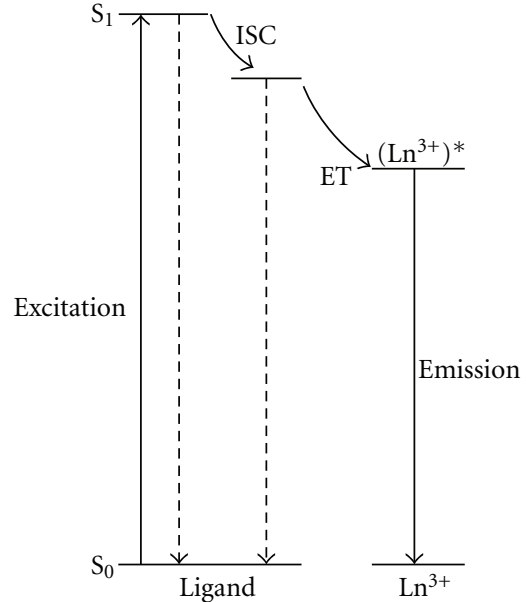

FIgURE 3: A schematic energy level diagram showing the origins of lanthanide luminescence through indirect excitation.

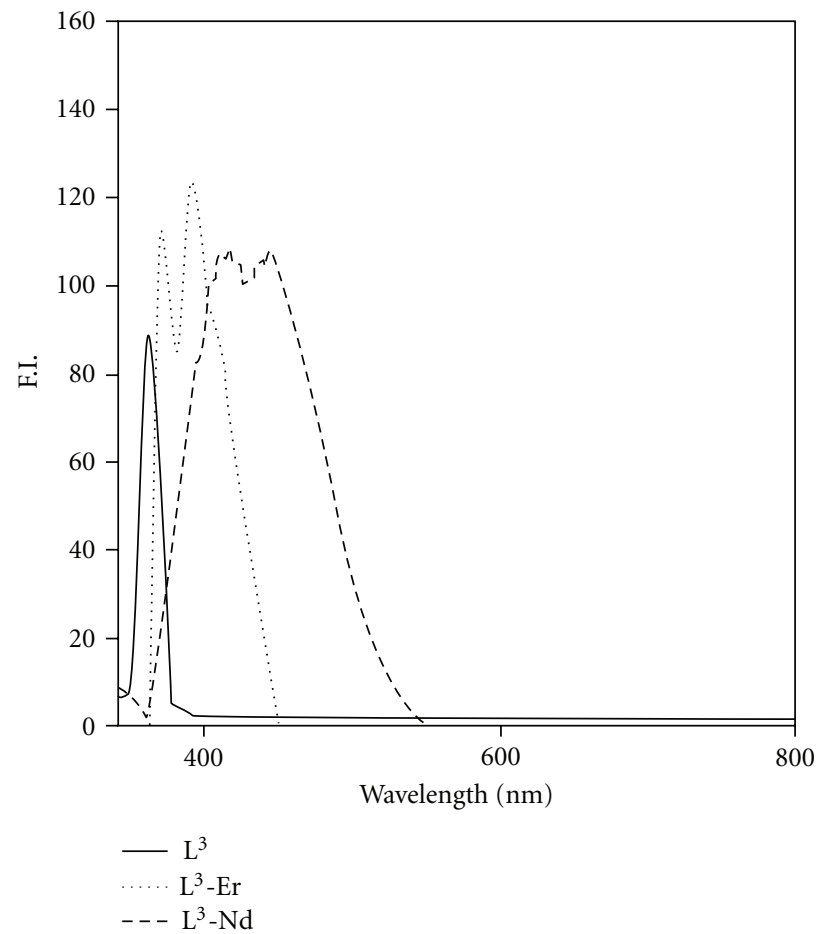

FIGURE 4: Emission spectra of $\mathrm{L}^{3}$ and its neodymium and erbium complexes in DMF $\left(5 \times 10^{-7} \mathrm{~mol} \mathrm{~L}^{-1}\right)$<smiles></smiles>

Scheme 1: The center of chelation in $\mathrm{L}^{1}$ Schiff base. 


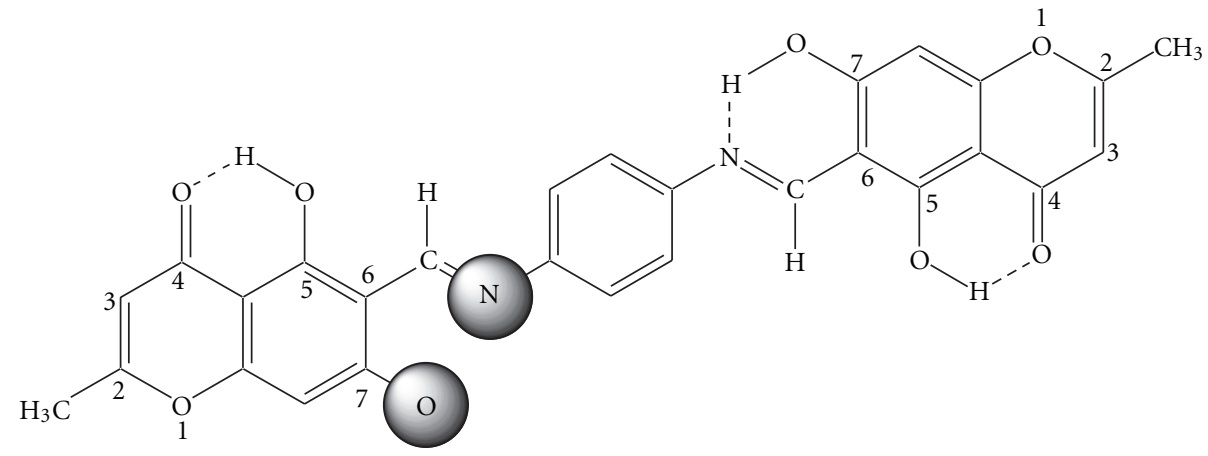

Scheme 2: The center of chelation in $\mathrm{L}^{2}$ Schiff base in mononuclear complexes.

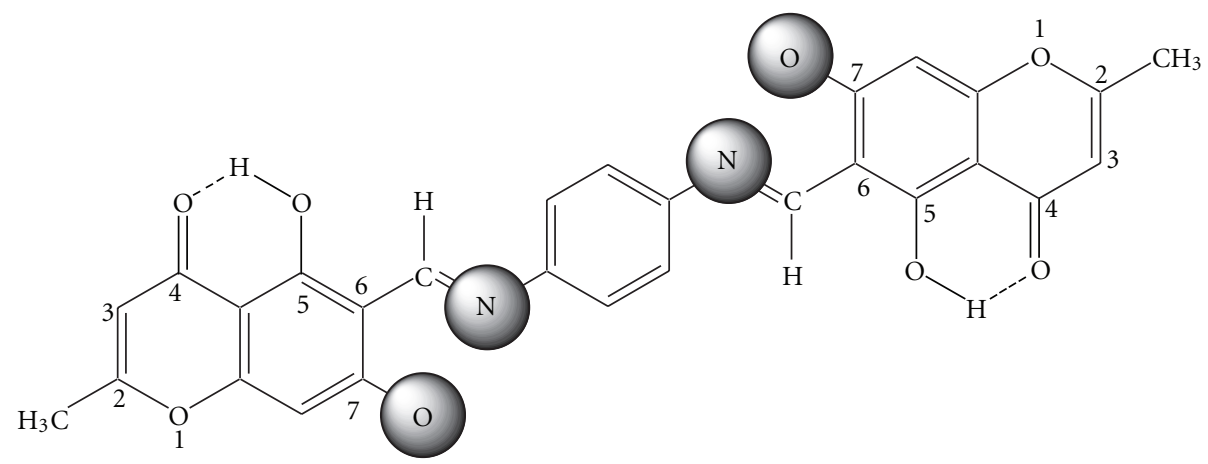

Scheme 3: The center of chelation in $\mathrm{L}^{2}$ Schiff base in binuclear complexes.<smiles></smiles>

Scheme 4: The center of chelation in $\mathrm{L}^{3}$ Schiff base in La- $\mathrm{L}^{3}$ complex.<smiles>Cc1cc(=O)c2c(-c3ccccc3)c(/C=N/c3ccccc3/N=C/c3cc(O)c4oc(C)cc(=O)c4c3O)c(C)cc2o1</smiles>

Scheme 5: The center of chelation in $\mathrm{L}^{3}$ Schiff base in $\mathrm{Nd}-\mathrm{L}^{3}$ complex.

is $\left[\mathrm{Ln}_{2} \mathrm{~L}^{2} \cdot 2 \mathrm{NO}_{3} \cdot \mathrm{OH} \cdot 2 \mathrm{C}_{2} \mathrm{H}_{5} \mathrm{OH} \cdot 3 \mathrm{H}_{2} \mathrm{O}\right] \cdot \mathrm{NO}_{3} \cdot \mathrm{nH}_{2} \mathrm{O}, \mathrm{Ln}=$ $\mathrm{La}(\mathrm{III}), \mathrm{Nd}(\mathrm{III})$, or $\operatorname{Er}(\mathrm{III})$ and $n=0,1$, or 3 .

In $\mathrm{L}^{3}$ Schiff base the structure of separated complexes depends on the type of metal ion, lanthanum complex was separated as $(1: 1)(\mathrm{M}: \mathrm{L})$, and the chelation occurs via the deprotonated $\mathrm{OH}$ protons in position seven of the two benzopyran-4-one moieties and the two nitrogen of azomethine group, and the Schiff base acts as dibasic tetradentate ligand, Scheme 4 , and the formula of this complex is $\left[\mathrm{La} \mathrm{L}^{3}\right.$. $\left.\mathrm{NO}_{3} \cdot \mathrm{C}_{2} \mathrm{H}_{5} \mathrm{OH}\right] \cdot 2 \mathrm{H}_{2} \mathrm{O}$. 


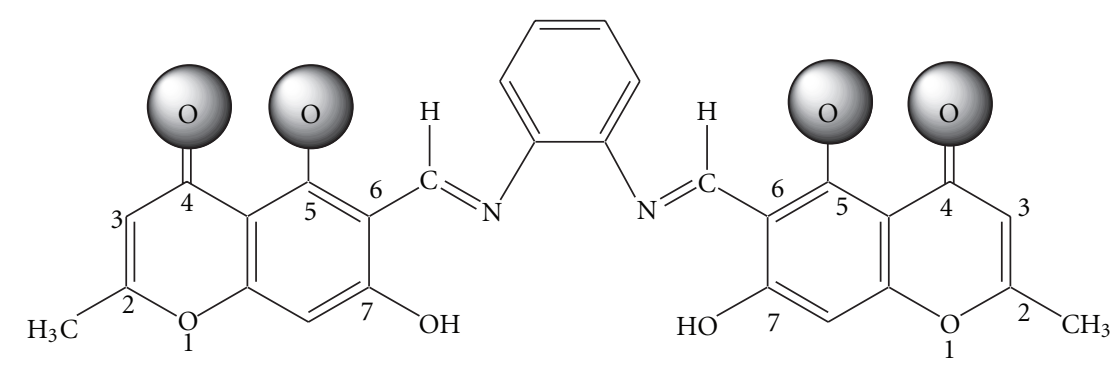

Scheme 6: The center of chelation in $\mathrm{L}^{3}$ Schiff base in $\mathrm{Er}_{2}-\mathrm{L}^{3}$ complex.

Neodymium forms with $\mathrm{L}^{3}$ mononuclear complex in which the Schiff base acts as a bidentate ligand (OO), and the chelation occurs via the oxygen of carbonyl group in position four and the deprotonated phenolic oxygen atom in position five of benzopyrone, Scheme 5 . The formula of this complex is $\left[\mathrm{Nd} \mathrm{L}^{3} \cdot \mathrm{NO}_{3} \cdot \mathrm{C}_{2} \mathrm{H}_{5} \mathrm{OH} \cdot \mathrm{H}_{2} \mathrm{O}\right] \cdot \mathrm{OH}$.

While erbium forms with $\mathrm{L}^{3}$ binuclear complex with formula of $\left[\mathrm{Er}_{2} \mathrm{~L}_{3} \cdot 2 \mathrm{NO}_{3} \cdot 4 \mathrm{H}_{2} \mathrm{O}\right] \cdot 2 \mathrm{OH} \cdot \mathrm{H}_{2} \mathrm{O}$, and the chelation occurs through the two carbonyl groups in position four and two deprotonated $\mathrm{OH}$ groups in position five of the two benzopyran-4-one moieties, Scheme 6.

\section{Conclusion}

In this paper, we report the preparation, elemental analyses, IR, ${ }^{1} \mathrm{H}-\mathrm{NMR}$, UV-vis spectra and thermal analysis to elucidate the structure of the solid complexes of lanthanide nitrates with a new Schiff bases of 5,7-dihydroxy-6-formyl-2methylbenzopyran-4-one and aromatic amines, which can form stable solid complexes. The following conclusions can be drawn concerning the ligating properties of the Schiff bases. The data elucidate three different modes of chelation of the Schiff bases. In the metal complexes, the Schiff bases behave as mono-negative (OO) bidentate ligand, and the chelation occurs via the oxygen of carbonyl group in position four, and the deprotonated phenolic oxygen atom in position five of benzopyrone (Schiff base $\mathrm{L}^{1}$ with three metal ions and $\mathrm{L}^{3}$ with $\operatorname{Er}(\mathrm{III})$ and $\mathrm{Nd}(\mathrm{III})$ ions) acts as monobasic (NO) bidentate ligand through the nitrogen atom of one of the two azomethine groups and one of the deprotonated phenolic oxygen atoms in position seven of the benzopyrone moiety (Schiff base $\mathrm{L}^{2}$ ) or behaves as dinegative $\mathrm{N}_{2} \mathrm{O}_{2}$ tetradentate ligands as in La- $\mathrm{L}^{3}$ complex, coordination occurring via the two azomethine nitrogen and the two deprotonated phenolic oxygen atoms in position seven of the benzopyrone moiety. All separated complexes are $(1: 1)(\mathrm{M}: \mathrm{L})$. The binuclear complexes of $\operatorname{Er}(\mathrm{III})$ ion with $\mathrm{L}^{3}$ and the three metal ions with $\mathrm{L}^{2}$ are only separated under the experimental conditions. The emission spectra of the free ligands and their neodymium and erbium complexes in DMF solutions at a concentration of $5 \times 10^{-7} \mathrm{M}$ were studied. Under the excitation, the neodymium and erbium complexes exhibited characteristic fluorescence. Based on those results, a series of new ligands could be designed and synthesized to optimize the luminescent properties of these lanthanide ions.

\section{References}

[1] N. Sabbatini, M. Guardigli, and J. M. Lehn, "Luminescent lanthanide complexes as photochemical supramolecular devices," Coordination Chemistry Reviews, vol. 123, no. 1-2, pp. 201228, 1993.

[2] P. A. Vigato and S. Tamburini, "The challenge of cyclic and acyclic schiff bases and related derivatives," Coordination Chemistry Reviews, vol. 248, no. 17-20, pp. 1717-2128, 2004.

[3] V. Alexander, "Design and synthesis of macrocyclic ligands and their complexes of lanthanides and actinides," Chemical Reviews, vol. 95, no. 2, pp. 273-342, 1995.

[4] C. Benelli and D. Gatteschi, "Magnetism of lanthanides in molecular materials with transition-metal ions and organic radicals," Chemical Reviews, vol. 102, no. 6, pp. 2369-2387, 2002.

[5] A. Døssing, "Luminescence from lanthanide(3+) ions in solution," European Journal of Inorganic Chemistry, no. 8, pp. 1425-1434, 2005.

[6] J. C. G. Bünzli and C. Piguet, "Lanthanide-containing molecular and supramolecular polymetallic functional assemblies," Chemical Reviews, vol. 102, no. 6, pp. 1897-1928, 2002.

[7] A. D. Sherry and C. F. G. C. Geraldes, "Lanthanide probes in life: chemical and earth sciences," in Theory and Practice, G. R. Choppin, Ed., vol. 93, Elsevier, Amsterdam, The Netherlands, 1989.

[8] D. Parker, R. S. Dickins, H. Puschmann, C. Crossland, and J. A. K. Howard, "Being excited by lanthanide coordination complexes: aqua species, chirality, excited-state chemistry, and exchange dynamics," Chemical Reviews, vol. 102, no. 6, pp. 19772010, 2002.

[9] M. Taniguchi and K. Takahei, "Optical properties of the dominant Nd center in GaP," Journal of Applied Physics, vol. 73, no. 2, pp. 943-947, 1993.

[10] J. P. Costes, F. Dahan, A. Dupuis, and J. P. Laurent, "A general route to strictly dinuclear $\mathrm{Cu}(\mathrm{II}) / \mathrm{Ln}(\mathrm{III})$ complexes. Structural determination and magnetic behavior of two $\mathrm{Cu}(\mathrm{II}) / \mathrm{Gd}(\mathrm{III})$ complexes," Inorganic Chemistry, vol. 36, no. 16, pp. 3429-3433, 1997.

[11] A. Bencini, C. Benelli, A. Caneschi, R. L. Carlin, A. Dei, and D. Gatteschi, "Crystal and molecular structure of and magnetic coupling in two complexes containing gadolinium(III) and copper(II) ions," Journal of the American Chemical Society, vol. 107, no. 26, pp. 8128-8136, 1985. 
[12] J. Lisowski and P. Starynowicz, "Heterodinuclear macrocyclic complexes containing both nickel(II) and lanthanide(III) ions," Inorganic Chemistry, vol. 38, no. 6, pp. 1351-1355, 1999.

[13] V. Alexander, "Design and synthesis of macrocyclic ligands and their complexes of lanthanides and actinides," Chemical Reviews, vol. 95, no. 2, pp. 273-342, 1995.

[14] V. De Zea Bermudez, R. A. Sá Ferreira, L. D. Carlos, C. Molina, K. Dahmouche, and S. J. L. Ribeiro, "Coordination of $\mathrm{Eu}^{3+}$ ions in siliceous nanohybrids containing short polyether chains and bridging urea cross-links," Journal of Physical Chemistry B, vol. 105, no. 17, pp. 3378-3386, 2001.

[15] C. Reinhard and H. U. Güdel, "High-resolution optical spectroscopy of $\mathrm{Na}_{3}\left[\mathrm{Ln}(\mathrm{dpa})_{3}\right] \cdot 13 \mathrm{H}_{2} \mathrm{O}$ with $\mathrm{Ln}=\mathrm{Er}^{3+}, \mathrm{Tm}^{3+}$, $\mathrm{Yb}^{3+}$," Inorganic Chemistry, vol. 41, no. 5, pp. 1048-1055, 2002.

[16] C. V. K. Sharma and R. D. Rogers, "Molecular chiness blinds': Self-organization of tetranitrato lanthanide complexes into open, chiral hydrogen-bomded networks," Chemical Communications, no. 1, pp. 83-84, 1999.

[17] Y. Liang, R. Cao, W. Su, M. Hong, and W. Zhang, "Syntheses, structures, and magnetic properties of two gadolinium (III) Copper (II) coordination polymers by a hydrothermal reaction," Angewandte Chemie -International Edition, vol. 39, no. 18, pp. 3304-3307, 2000.

[18] Y. Liang, M. Hong, W. Su, R. Cao, and W. Zhang, "Preparations, structures, and magnetic properties of a series of novel copper(II)-lanthanide(III) coordination polymers via hydrothermal reaction," Inorganic Chemistry, vol. 40, no. 18, pp. 4574-4582, 2001.

[19] R. Cao, D. Sun, Y. Liang, M. Hong, K. Tatsumi, and Q. Shi, "Syntheses and characterizations of three-dimensional channel-like polymeric lanthanide complexes constructed by 1,2 , 4,5-benzenetetracarboxylic acid," Inorganic Chemistry, vol. 41, no. 8, pp. 2087-2094, 2002.

[20] Z. Wang, C.-M. Jin, T. Shao et al., "Syntheses, structures, and luminescence properties of a new family of three-dimensional open-framework lanthanide coordination polymers," Inorganic Chemistry Communications, vol. 5, no. 9, pp. 642-648, 2002.

[21] L. Pan, X. Huang, J. Li, Y. Wu, and N. Zheng, "Novel singleand double-layer and three-dimensional structures of rareEarth metal coordination polymers: the effect of lanthanide contraction and acidity control in crystal structure formation," Angewandte Chemie-International Edition, vol. 39, no. 3, pp. 527-530, 2000.

[22] J. P. Costes, J. M. Clemente, F. Dahan, F. Nicodème, and M. Verelst, "Unprecedented ferromagnetic interaction in homobinuclear erbium and gadolinium complexes: structural and magnetic studies," Angewandte Chemie-International Edition, vol. 41, no. 2, pp. 323-325, 2002.

[23] A. Ouchi, Y. Suzuki, Y. Ohki, and Y. Koizumi, "Structure of rare earth carboxylates in dimeric and polymeric forms," Coordination Chemistry Reviews, vol. 92, pp. 29-43, 1988.

[24] A. Panagiotopoulos, T. F. Zafiropoulos, S. P. Perlepes et al., "Molecular structure and magnetic properties of acetatobridged lanthanide(III) dimers," Inorganic Chemistry, vol. 34, no. 19 , pp. 4918-4920, 1995.

[25] F. Aydogan, N. Öcal, Z. Turgut, and C. Yolacan, "Transformations of aldimines derived from pyrrole-2-carbaldehyde. Synthesis of thiazolidino-fused compounds," Bulletin of the Korean Chemical Society, vol. 22, no. 5, pp. 476-480, 2001.

[26] M. A. V. Ribeiro Da Silva, M. D. M. C. Ribeiro Da Silva, M. J. S. Monte, J. M. Gonçalves, and E. M. R. Fernandes, "Energetics of metal-ligand binding in copper(II) and nickel(II) complexes of two Schiff bases," Journal of the Chemical Society-Dalton Transactions, no. 7, pp. 1257-1262, 1997.

[27] B.-D. Wang, Z.-Y. Yang, D.-W. Zhang, and Y. Wang, "Synthesis, structure, infrared and fluorescence spectra of new rare earth complexes with 6-hydroxy chromone-3-carbaldehyde benzoyl hydrazone," Spectrochimica Acta A, vol. 63, no. 1, pp. 213-219, 2006.

[28] M. T. El-Haty, F. A. Adam, A. E. Mohamed, and A. A. Gabr, "Electronic spectra of some heterocyclic schiff bases derived from 3-amino-1,2,4-triazole," Journal of the Indian Chemical Society, vol. 67, no. 9, pp. 743-747, 1990.

[29] A. L. El-Ansary, H. M. Abdel-Fattah, and N. S. Abdel-Kader, "Synthesis and characterization of tetradentate bis-Schiff base complexes of di- and tri-valent transition metals," Journal of Coordination Chemistry, vol. 61, no. 18, pp. 2950-2960, 2008.

[30] A. I. Vogel, Practical Organic Chemistry Including Quantitative Organic Analysis, Longmans, London, UK, 5th edition, 1991.

[31] W. J. Geary, "The use of conductivity measurements in organic solvents for the characterisation of coordination compounds," Coordination Chemistry Reviews, vol. 7, no. 1, pp. 81-122, 1971.

[32] F. B. Tamboura, M. Diop, M. Gaye, A. S. Sall, A. H. Barry, and T. Jouini, "X-ray structure and spectroscopic properties of some lanthanides(III) complexes derived from 2,6-diacetylpyridine-bis(benzoylhydrazone)," Inorganic Chemistry Communications, vol. 6, no. 8, pp. 1004-1010, 2003.

[33] L. J. Bellamy, The Infrared Spectra of Complex Molecules, Chapman and Hall, London, UK, 1975.

[34] B. S. Saraswat, G. Srivastava, and R. C. Mehrotra, "Schiff base complexes of organotin(IV). Reactions of trialkyltin(IV) chlorides and alkoxides with N-substituted salicylideneimines," Journal of Organometallic Chemistry, vol. 129, no. 2, pp. 155161, 1977.

[35] S. J. Gruber, C. M. Harris, and E. Sinn, "Metal complexes as ligands-IV $[1,2,3]$. Bi- and Tri- nuclear complexes derived from metal complexes of tetradentate salicylaldimines," Journal of Inorganic and Nuclear Chemistry, vol. 30, no. 7, pp. 1805-1830, 1968.

[36] R. C. Mourya, R. Varma, and P. Shukla, "Synthesis of nitrato complexes of lanthanum(III) with schiff bases derived from 4-antipyrinecarboxaldehyde and aromatic amines," Journals of the Indian Chemical Society, vol. 74, no. 9, pp. 789-790, 1997.

[37] A. M. Donia and H. A. El-Boraey, "Preparation of highly insulating dimeric and polymeric metal complexes with higher thermal stability in the solid state," Journal of Analytical and Applied Pyrolysis, vol. 63, no. 1, pp. 69-84, 2002.

[38] S. K. Sengupta, O. P. Pandey, B. K. Srivastava, and V. K. Sharma, "Synthesis, structural and biochemical aspects of titanocene and zirconocene chelates of acetylferrocenyl thiosemicarbazones," Transition Metal Chemistry, vol. 23, no. 4, pp. 349-353, 1998.

[39] B.-D. Wang, Z.-Y. Yang, and T.-R. Li, "Synthesis, characterization, and DNA-binding properties of the $\mathrm{Ln}$ (III) complexes with 6-hydroxy chromone-3-carbaldehyde-(2'-hydroxy) benzoyl hydrazone," Bioorganic and Medicinal Chemistry, vol. 14, no. 17, pp. 6012-6021, 2006.

[40] S. P. Sinha, Complexes of the Rare Earths, Pergamon Press, Oxford, UK, 1966.

[41] U. K. Pandey, O. P. Pandey, S. K. Sengupta, and S. C. Tripathi, "Syntheses and spectroscopic studies on tetraaza macrocyclic complexes of praseodymium(III)," Polyhedron, vol. 6, no. 7, pp. 1611-1617, 1987. 
[42] C. N. R. Rao, Chemical Application of Infrared Spectroscopy, Academic Press, New York, NY, USA, 1963.

[43] G. F. Liu, Y. N. Zhao, and X. X. Liu, "Preparation and characterization of coordination compounds on rare earth nitrate with Schiff base derived from o-vanillin and 1-naphthylamine," Acta Chimica Sinica, vol. 50, no. 5, pp. 473-478, 1992.

[44] Z. A. Tahaa, A. M. Ajlounia, K. A. Al-Hassan, A. K. Hijazi, and A. B. Faiq, "Syntheses, characterization, biological activity and fluorescence properties of bis-(salicylaldehyde)-1,3-propylenediimine schiff base ligand and its lanthanide complexes," Spectrochimica Acta Part A, vol. 81, no. 1, pp. 317-323, 2011.

[45] X. M. He and C. H. Song, Chinese Journal of Synthetic Chemistry, vol. 10, p. 245, 2002.

[46] R. Yang, S.-Y. He, W.-T. Wu, Q.-Z. Shi, and D.-Q. Wang, "Crystal structure, fluorescence properties and thermal stability of supra-molecule complex $\left[\mathrm{Eu}\left(\mathrm{C}_{10} \mathrm{H}_{9} \mathrm{~N}_{2} \mathrm{O}_{4}\right)\right.$. $\left.\left(\mathrm{C}_{10} \mathrm{H}_{8} \mathrm{~N}_{2} \mathrm{O}_{4}\right) \cdot\left(\mathrm{H}_{2} \mathrm{O}\right)_{3}\right]_{2} \cdot$ phen $4 \mathrm{H}_{2} \mathrm{O}$," Chemical Journal of Chinese Universities, vol. 26, no. 3, pp. 401-406, 2005.

[47] Y. Hirashima, K. Kanetsuki, I. Yonezu, k. Kamakura, and J. Shiokawa, "Lanthanoid nitrate complexes with some polyethylene glycols and glymes," Bulletin of the Chemical Society of Japan, vol. 56, no. 3, pp. 738-743, 1983.

[48] E. Katsoulakou, V. Bekiari, C. P. Raptopoulouc et al., "Dinuclear versus tetranuclear cluster formation in zinc(II) nitrate/di-2-pyridyl ketone chemistry: synthetic, structural and spectroscopic studies," Spectrochimica Acta A, vol. 61, no. 7, pp. 1627-1638, 2005.

[49] Y.-L. Zhang, W.-S. Liu, W. Dou, and W.-W. Qin, "Synthesis and infrared and fluorescence spectra of new europium and terbium polynuclear complexes with an amide-based 1,10phenanthroline derivative," Spectrochimica Acta A, vol. 60, no. 8-9, pp. 1707-1711, 2004.

[50] K. Nakamoto, Infrared and Raman Spectra of Inorganic and Coordination Compounds, Wiley Intersciences, New York, NY, USA, 3rd edition, 1978.

[51] A. P. Hunter, A. M. J. Lees, and A. W. G. Platt, "Synthesis, structures and mass spectrometry of lanthanide nitrate complexes with tricyclohexylphosphine oxide," Polyhedron, vol. 26, no. 17, pp. 4865-4876, 2007.

[52] Y. M. Issa, A. L. El-Ansary, O. E. Sherif, and M. M. ElAjily, "Separation and spectroscopic characterization of new metal chelates of 8-arylazo-6-formyl-7-hydroxy-5-methoxy2-methyl chromones," Transition Metal Chemistry, vol. 22, no. 5, pp. 441-446, 1997.

[53] A. M. El-Roudi, Bulletin of the Faculty of Science, vol. 18, p. 77, 1989.

[54] F. A. Aly, S. M. Abu-El-Wafa, R. M. Issa, and F. A. El-Sayed, "On the formation of mononuclear and binuclear complexes of pentadentate $\mathrm{N}_{4} \mathrm{O}_{2}$ schiff base ligands with $\mathrm{Co}(\mathrm{II}), \mathrm{Ni}(\mathrm{II})$ and $\mathrm{Cu}(\mathrm{II})$ ions: TGA, spectral and conductance studies," Thermochimica Acta, vol. 126, pp. 235-244, 1988.

[55] G. Rijulal and P. Indrasenan, "Synthesis and characterization of some lanthanide(III) complexes with 4-[N-(2-methoxybenzylimine)formyl]-2, 3-dimethyl-1-phenyl-3-pyazolin-5one," Journal of Rare Earths, vol. 25, no. 6, pp. 670-673, 2007.

[56] G. Zhao, Y. Feng, and Y. Wen, "Syntheses, crystal structures and kinetic mechanisms of thermal decomposition of rare earth complexes with Schiff base derived from o-vanillin and p-toluidine," Journal of Rare Earths, vol. 24, no. 3, pp. 268-275, 2006.

[57] R. D. Archer, H. Chen, and L. C. Thompson, "Synthesis, characterization, and luminescence of europium(III) Schiff base complexes," Inorganic Chemistry, vol. 37, no. 8, pp. 2089-2095, 1998. 


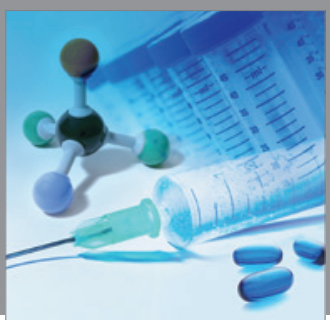

International Journal of

Medicinal Chemistry

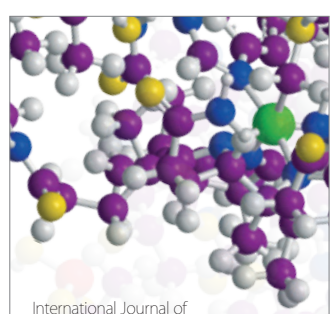

Carbohydrate Chemistry

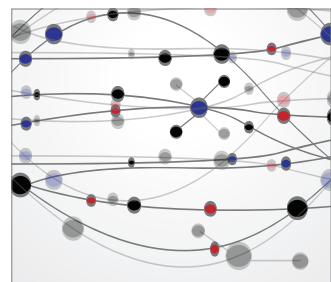

The Scientific World Journal
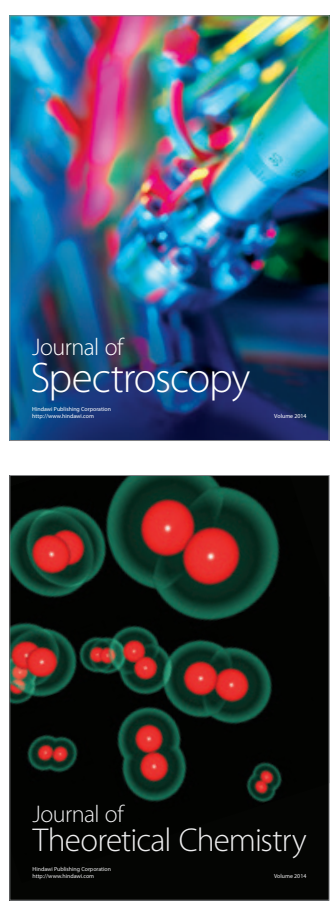
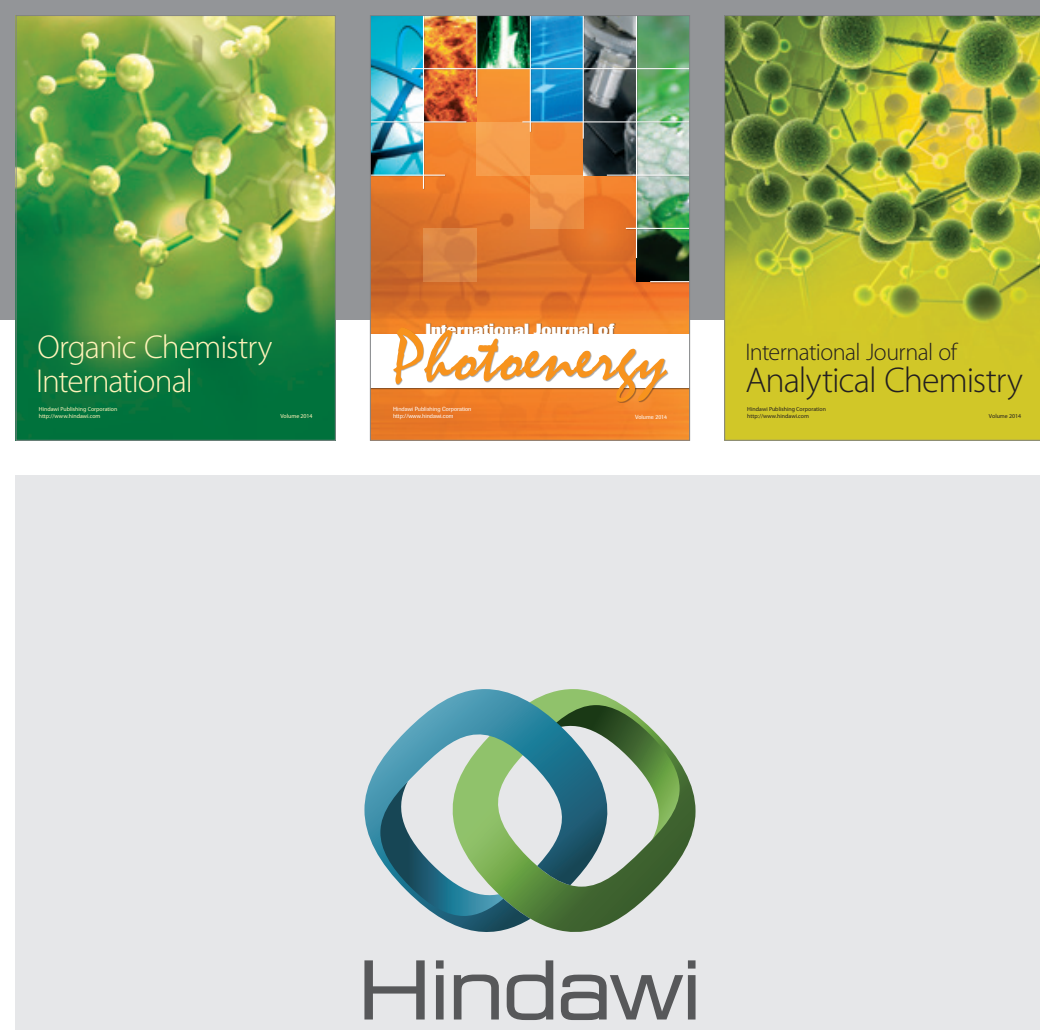

Submit your manuscripts at

http://www.hindawi.com
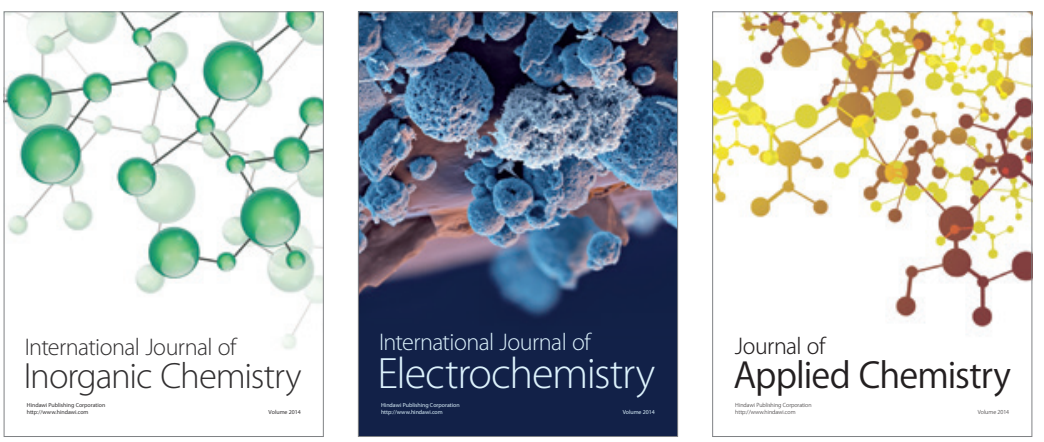

Journal of

Applied Chemistry
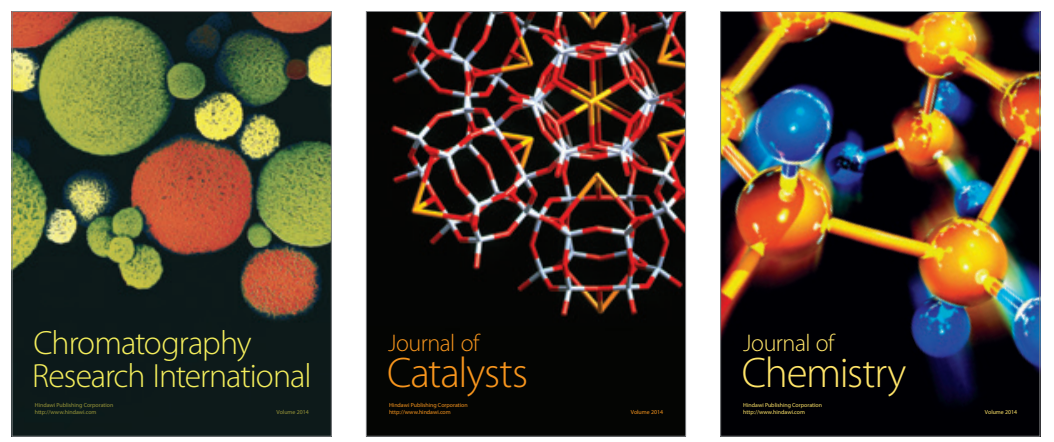
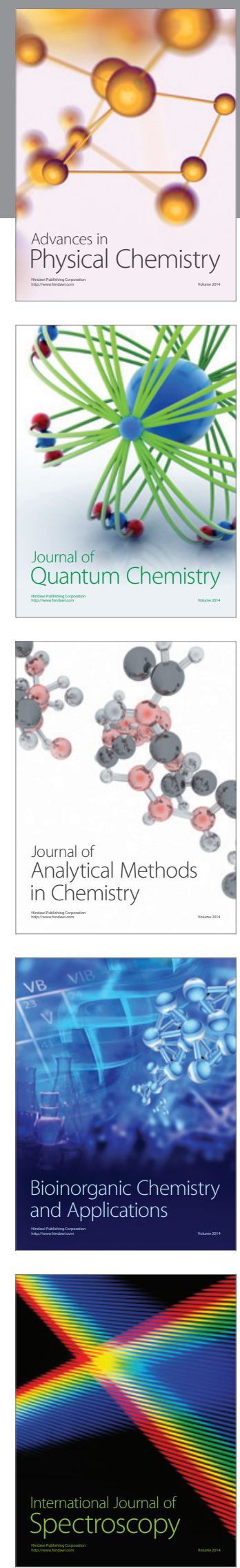